\title{
Quality of soybean seeds with high mechanical damage index after processing and storage
}

\author{
José M. G. Neves ${ }^{1}$, João A. Oliveira ${ }^{2}$, Humberto P. da Silva², \\ Rodrigo de G. E. Reis ${ }^{3}$, Jacson Zuchi ${ }^{4}$ \& Antônio R. Vieira ${ }^{5}$ \\ ${ }^{1}$ Instituto Federal de Educação, Ciências e Tecnologia do Piauí/Departamento de Agricultura. Oeiras, PI. E-mail: josemariauf@yahoo.com.br (Corresponding \\ author) \\ ${ }^{2}$ Universidade Federal de Lavras/Departamento de Agricultura. Lavras, MG. E-mail: jalmir@dag.ufla.br; humberto.agrosilva@yahoo.com.br \\ ${ }^{3}$ Universidade do Estado de Mato Grosso/Departamento de Fitotecnia. Nova Xavantina, MT. E-mail: guidegoes@gmail.com \\ ${ }^{4}$ Instituto Federal Goiano/Rede Arco Norte - Polo de Inovação. Rio Verde, GO. E-mail: jacson.zuchi@ifgoiano.edu.br \\ ${ }^{5}$ Empresa de Pesquisa Agropecuária de Minas Gerais/Centro Tecnológico do Sul de Minas. Lavras, MG. E-mail: aroberiovieira@gmail.com
}

\section{Key words:}

Glycine max

seed processing

vigor

health

\begin{abstract}
A B S T R A C T
This study aimed to evaluate the quality of soybean seeds with high level of mechanical damages from different processing stages and stored with and without fungicide treatment. Collections of seed samples were performed during the processing at the following points: hopper, pre-cleaning, dryer, cleaning, spiral, sieve-classifier and the gravity table. The experimental design was completely randomized in a $9 \times 2$ factorial scheme, with 9 collection points and two seed treatments, in four replicates. The seeds were then evaluated immediately after processing and after six months of storage. The processing progressively improved the attributes of soybean seed quality throughout the different stages in which the gravity table plays an important role in the improvement of the physiological and sanitary quality of the lot, favoring the storage potential and vigor of the seeds. The treatment of the seeds with fungicides is effective in controlling fungi before and after storage. The storage of soybean seeds with high level of mechanical damage markedly increases their deterioration.
\end{abstract}

\section{Palavras-chave: \\ Glycine max \\ beneficiamento de sementes \\ vigor \\ sanidade}

\section{Qualidade de sementes de soja com alto índice de danos mecânicos após beneficiamento e armazenamento}

Ref. 168-2015 - Received 24 Nov, 2015 • Accepted 15 Sept, 2016 • Published 29 Sept, 2016 


\section{INTRODUCTION}

The quality and viability of soybean seeds during storage depend on the initial quality and on the storage conditions of the lot. The soybean seed is susceptible to the mechanical damages that occur during the harvest, drying and processing, which may negatively influence seed viability and vigor during the storage (Maryam \& Oskouie, 2011).

The use of soybean seeds with high standards of physical, genetic, physiological and sanitary quality has been the great difference in the successful establishment of the crop at the field (Silva et al., 2011a). In this context, it is unquestionable the relevance of seed processing for the efficiency of the production process. However, due to the morphological arrangement of soybean seeds, which provides little protection to the embryonic axis, since it is situated on a tegument that is not much thick (Lopes et al., 2011), the seeds become more susceptible to the mechanical damages considered as the main cause of the reduction in seed quality during the entire production process.

Factors such as water content and genetic variability cause large influences on the susceptibility of the seeds to mechanical damages (Silva et al., 2011b). In many cases, these damages are not sufficient to destroy the structures of the seeds, but cause the appearance of cracks that lead to abnormalities in the seedlings, higher susceptibility to the action of microorganisms and higher sensitivity to chemical treatments, thus reducing the quality and storage potential of the lots.

Therefore, the main benefits for soybean production with the use of seeds of better quality for planting constitute a factor of extreme importance to obtain an adequate establishment of plants at the field, resulting in higher yields (Giurizatto et al., 2008).

Based on the above, this study aimed to evaluate the quality of soybean seeds after the different processing stages and after the storage with and without fungicide treatment.

\section{Material AND Methods}

The experiment was carried out at the Laboratory of Seed Analysis and at the Laboratory of Seed Pathology of the Departments of Agriculture and Phytopathology of the Federal University of Lavras (UFLA). The experiment used seeds of soybean (Glycine max (L.) Merril), cultivar M 8230 $\mathrm{RR}$, from the field of production of basic seeds of the company Monsoy, processed at the company Sementes Vitória Ltda., in Rio Verde, GO.

During the processing and after each device, 20 single samples were collected in all treatments every $2 \mathrm{~min}$ at the following collection points: T1 - hopper; T2 - pre-cleaning; T3 - dryer; T4 - cleaning; T5 - spiral; T6 - 6.0 sieve-classifier; T7 - 5.5 sieve-classifier; T8 -6.0 sieve-gravity table and T9 5.5 sieve-gravity table. All single samples were homogenized to form a composite sample of $4 \mathrm{~kg}$ for the analyses of physical, physiological and sanitary quality.

Half of the composite sample $(2 \mathrm{~kg})$ of the seeds obtained at each point was treated with the mixture of fungicides Carbendazim + Thiram, with commercial name of Derosal
Plus, at the dose of $200 \mathrm{~mL} 100 \mathrm{~kg}^{-1}$ of seeds, while the other half was not treated. The seed samples were placed in paper bags and stored at ambient temperature for a period of 180 days.

The seeds were subjected to the following tests and/or determinations:

Water content: Performed using two 4-g samples per treatment through the method of the oven at $105 \pm 3{ }^{\circ} \mathrm{C}$ for 24 h (Brasil, 2009).

Germination: Performed with four replicates of 50 seeds distributed in substrate of paper, moistened with distilled water at the proportion of 2.5 times the weight of the dry paper, and placed to germinate at temperature of $25{ }^{\circ} \mathrm{C}$. The evaluations were performed 5 days after sowing, calculating the final percentage of normal seedlings (Brasil, 2009).

Electrical conductivity: Performed using four replicates of 50 seeds, physically pure, of each sample. After weighing, the seeds were subjected to imbibition in plastic cup with 75 $\mathrm{mL}$ of deionized water and maintained at $25^{\circ} \mathrm{C}$ for $24 \mathrm{~h}$ and only then controlled. At the end of the period, the electrical conductivity of the solution was determined in a conductivity meter (DIGIMED CD-21). The results were expressed in $\mu \mathrm{S}$ $\mathrm{cm}^{-1} \mathrm{~g}^{-1}$ of seeds (Vieira \& Krzyzanowski, 1999).

Accelerated aging: Performed using Gerbox-type plastic boxes with individual compartment; a single layer (40-42 g) of seeds from each treatment was placed on the internal metal screen of the box, covering its entire surface. The closed boxes were subjected to the germination test as previously described for the evaluation of the percentage of normal seedlings on the $5^{\text {th }}$ day after sowing.

Test for the identification of mechanical damages: Performed using two subsamples of 100 seeds for each replicate, placed in a plastic cup and covered with solution of $1 \%$ sodium hypochlorite, for $10 \mathrm{~min}$; after this period, the seeds were distributed on sheets of paper towel, the number of swollen seeds was counted and the results were expressed in mean percentage per treatment (Krzyzanowski et al., 2004).

Tetrazolium test: Conducted using four subsamples of 50 seeds per treatment, which were subjected to imbibition in Germitest paper roll, for $16 \mathrm{~h}$ and in an oven regulated at $25^{\circ} \mathrm{C}$. After this period, the seeds were transferred to plastic cups, immersed in tetrazolium solution at the concentration of $0.075 \%$ and placed in BOD chamber at $40{ }^{\circ} \mathrm{C}$ for $3 \mathrm{~h}$. After this period, the seeds were analyzed for the levels of vigor (TZ 1-3 class), viability (TZ 1-5 class) and the diagnosis of quality loss (TZ 1-8 and TZ 6-8 classes), in this case identifying the causes of the loss of physiological quality of the seeds. The results were expressed in percentage (França Neto et al., 1999).

Seed health: The seeds were incubated in Petri dishes with diameter of $15 \mathrm{~cm}$ containing two sheets of filter paper moistened with water $+2,4 \mathrm{D}$ (sodium 2,4-dichlorophenoxyacetate) at $0.02 \% .50$ seeds of each treatment were used per dish, in a total of four subsamples and 200 seeds. The dishes were maintained in an incubation room at $20^{\circ} \mathrm{C}$ with photoperiod of $12 \mathrm{~h}$ for seven days and, later, the incidence of pathogens was quantified.

The statistical design was completely randomized in a $9 \times 2$ factorial scheme, with 9 collection points and 2 seed treatments (with fungicide and without fungicide) in four replicates, totaling 200 seeds per treatment. The seeds were 
evaluated immediately after processing and six months after processing. The data were subjected to analysis of variance and the means were compared by the Scott-Knott criterion at 0.05 probability level.

\section{Results AND Discussion}

The percentage of mechanical damages was higher in the first processing stage (hopper), significantly decreased in the pre-cleaning, due to the elimination of broken seeds, increased after the passing through the dryer and decreased after the passing through the 6.0 sieve (Table 1 ).

This high percentage of damages can be attributed to problems during the mechanical harvest and/or in the drying process. Similar results were found by Oliveira et al. (1999) working with soybean seeds, cv. Dourado, which showed 16.5 and $13.5 \%$ of damages, before and after pre-cleaning, respectively; however, the damages did not decrease along the processing, being cumulative. In seeds of the corn hybrid Ag-122, classified in 3 sieves, Paiva et al. (2000) observed high levels of damage after the processing stages, except for the dryer, and the seeds, regardless of their size, were susceptible to the physical injuries.

In the test of electrical conductivity, there was only difference between treated and untreated seeds, which showed means of 83.84 and $79.96 \mu \mathrm{S} \mathrm{cm}^{-1} \mathrm{~g}^{-1}$, respectively. This fact can be explained by the amount of leachates in the solution, influenced by the presence of the molecule of the active principle used in the treated seeds, which promoted higher electrical conductivity of the solution.

As to germination percentage of the seeds collected at each point of the processing (Table 2), there was a higher percentage of normal seedlings after cleaning, except for the collection point after the 5.5 sieve-classifier. Many studies confirm the improvement of physical and physiological quality of the seed lots after processing. Similar results were observed in: Arabica coffee (Giomo et al., 2004); fodder radish (Nery et al., 2009); sweet corn (Ferreira \& Sá, 2010), but not for peanut seeds (Fessel \& Barreto, 2000).

The result of the tetrazolium test showed improvements on seed vigor along the processing stages and, for the germination potential (TZ 1-5), only soybean seeds were collected after the

Table 1. Mean values of mechanical damages, electrical conductivity and the respective coefficients of variation (CV \%) of soybean seeds sampled along the processing line, evaluated immediately after the processing

\begin{tabular}{|c|c|c|}
\hline $\begin{array}{l}\text { Points } \\
\text { of collection }\end{array}$ & $\begin{array}{l}\text { Mechanical damage } \\
\text { by hypochlorite (\%) }\end{array}$ & $\begin{array}{c}\text { Electrical } \\
\text { conductivity }\left(\mu \mathrm{s} \mathrm{cm}^{-1} \mathrm{~g}^{-1}\right)\end{array}$ \\
\hline Hopper & $27.7 \mathrm{~A}$ & $87.7 \mathrm{~A}$ \\
\hline Pre-cleaning & $16.7 \mathrm{C}$ & $74.5 \mathrm{~A}$ \\
\hline Dryer & $24.5 \mathrm{~A}$ & $88.7 \mathrm{~A}$ \\
\hline Cleaning & $26.5 \mathrm{~A}$ & $74.3 \mathrm{~A}$ \\
\hline Spiral & $24.2 \mathrm{~A}$ & $80.5 \mathrm{~A}$ \\
\hline 6.0 sieve-classifier & $22.0 \mathrm{~B}$ & $80.4 \mathrm{~A}$ \\
\hline 5.5 sieve-classifier & $21.7 \mathrm{~B}$ & $89.2 \mathrm{~A}$ \\
\hline 6.0 sieve-gravity table & $20.0 B$ & $84.1 \mathrm{~A}$ \\
\hline 5.5 sieve-gravity table & $20.2 B$ & $81.7 \mathrm{~A}$ \\
\hline CV (\%) & 10.9 & 18.2 \\
\hline
\end{tabular}

Means followed by the same uppercase letter in the column do not differ by the Scott-Knot criterion $(p>0.05)$
Table 2. Mean values of germination $(\mathrm{G} \%)$, vigor potential (TZ 1-3), germination potential (TZ 1-5), potential of mechanical damages through tetrazolium (TZ 1-8), accelerated aging (AA\%) and the respective coefficients of variation ( $\mathrm{CV} \%$ ) of soybean seeds sampled along the processing line, evaluated immediately after the processing

\begin{tabular}{|c|c|c|c|c|c|}
\hline \multirow{2}{*}{$\begin{array}{c}\text { Points } \\
\text { of collection }\end{array}$} & \multirow{2}{*}{$\begin{array}{l}\text { G } \\
(\%)\end{array}$} & \multicolumn{3}{|c|}{ TZ } & \multirow{2}{*}{$\begin{array}{l}\text { AA } \\
(\%)\end{array}$} \\
\hline & & $(1-3)$ & $(1-5)$ & $(1-8)$ & \\
\hline Hopper & $67.5 \mathrm{~B}$ & $63.2 \mathrm{C}$ & $92.8 \mathrm{~A}$ & $15.0 \mathrm{~A}$ & $51.5 \mathrm{~B}$ \\
\hline Pre-cleaning & $70.0 \mathrm{~B}$ & $66.2 \mathrm{C}$ & $93.1 \mathrm{~A}$ & $11.8 \mathrm{~B}$ & $58.0 \mathrm{~B}$ \\
\hline Dryer & $70.2 \mathrm{~B}$ & $66.7 \mathrm{C}$ & $91.0 \mathrm{~B}$ & $15.1 \mathrm{~A}$ & $56.7 \mathrm{~B}$ \\
\hline Cleaning & $76.7 \mathrm{~A}$ & $69.5 \mathrm{C}$ & $91.1 \mathrm{~B}$ & $14.5 \mathrm{~A}$ & $55.2 \mathrm{~B}$ \\
\hline Spiral & $78.7 \mathrm{~A}$ & $68.5 \mathrm{C}$ & $94.7 \mathrm{~A}$ & $13.1 \mathrm{~B}$ & $58.0 \mathrm{~B}$ \\
\hline 6.0 sieve-classifier & $83.5 \mathrm{~A}$ & $74.0 \mathrm{~B}$ & $93.3 \mathrm{~A}$ & $13.0 \mathrm{~B}$ & $59.0 \mathrm{~B}$ \\
\hline 5.5 sieve-classifier & $72.7 \mathrm{~B}$ & $72.6 \mathrm{~B}$ & $93.2 \mathrm{~A}$ & $11.6 \mathrm{~B}$ & $61.7 \mathrm{~A}$ \\
\hline 6.0 sieve-gravity table & $80.5 \mathrm{~A}$ & $80.5 \mathrm{~A}$ & $93.6 \mathrm{~A}$ & $12.0 \mathrm{~B}$ & $65.8 \mathrm{~A}$ \\
\hline 5.5 sieve-gravity table & $80.5 \mathrm{~A}$ & $82.2 \mathrm{~A}$ & $93.6 \mathrm{~A}$ & $11.0 \mathrm{~B}$ & $63.8 \mathrm{~A}$ \\
\hline CV (\%) & 6.46 & 4.85 & 2.33 & 4.5 & 9.4 \\
\hline
\end{tabular}

Means followed by the same uppercase letter in the column do not differ by the Scott-Knott criterion $(p>0.05)$

dryer and the cleaning, and they showed lower germination potential (Table 2). This can be explained by possible damages caused during the drying process of the seeds, which may be correlated with the higher proportion of mechanical damages. Regarding vigor levels (TZ 1-3), soybean seeds showed lower vigor in the initial processing stages and then it increased, and seeds collected after the gravity table showed higher vigor. The potential of mechanical damages by tetrazolium (TZ 1-8) exhibited a behavior similar to that of the mechanical damages by hypochlorite.

There was a significant improvement in the percentage of normal seedlings, according to the test of accelerated aging, for the seeds collected after the 5.5 sieve-classifier and gravity table, which denotes the efficiency of the gravity table in the improvement of the physiological quality of the lot of soybean seeds.

Soybean seeds that were not treated with fungicide showed high incidence of Penicillium sp., Cladosporium sp. and Fusarium sp. It is observed that the fungicide treatment was highly efficient in the control of the fungi Cladosporium sp., Fusarium sp. and Penicillium sp. (Table 3).

Table 3. Percentage of occurrence of Cladosporium sp., Fusarium sp. and Penicillium sp., associated with soybean seeds collected at different points and the respective coefficients of variation ( $\mathrm{CV} \%$ ) using the blotting paper test, immediately after the processing

\begin{tabular}{|c|c|c|c|c|c|c|}
\hline \multirow{3}{*}{$\begin{array}{l}\text { Points } \\
\text { of collection }\end{array}$} & \multicolumn{2}{|c|}{ Clasdosporium sp. } & \multicolumn{2}{|c|}{ Fusarium sp. } & \multicolumn{2}{|c|}{ Penicillium sp. } \\
\hline & WO/F & $W / F$ & WO/F & $W / F$ & WO/F & $W / F$ \\
\hline & \multicolumn{6}{|c|}{$(\%)$} \\
\hline Hopper & $13.0 \mathrm{Ba}$ & $0.5 \mathrm{Ab}$ & $9.5 \mathrm{Aa}$ & $3.0 \mathrm{Ab}$ & $23.5 \mathrm{Ba}$ & $1.0 \mathrm{Bb}$ \\
\hline Pre-cleaning & $20.5 \mathrm{Aa}$ & $2.0 \mathrm{Ab}$ & $10.5 \mathrm{Aa}$ & $1.5 \mathrm{Ab}$ & $32.0 \mathrm{Aa}$ & $1.5 \mathrm{Bb}$ \\
\hline Dryer & $12.5 \mathrm{Ba}$ & $1.5 \mathrm{Ab}$ & $9.5 \mathrm{Aa}$ & $1.5 \mathrm{Ab}$ & $37.5 \mathrm{Aa}$ & $0.5 \mathrm{Bb}$ \\
\hline Cleaning & $8.0 \mathrm{Ba}$ & $0 A b$ & $8.0 \mathrm{Aa}$ & $0.0 \mathrm{Ab}$ & $39.0 \mathrm{Aa}$ & $1.0 \mathrm{Bb}$ \\
\hline Spiral & $10.0 \mathrm{Ba}$ & $0 \mathrm{Ab}$ & $7.5 \mathrm{Aa}$ & $1.0 \mathrm{Ab}$ & $26.5 \mathrm{Aa}$ & $1.0 \mathrm{Bb}$ \\
\hline 6.0 sieve-classifier & $18.0 \mathrm{Aa}$ & $0 \mathrm{Ab}$ & $5.0 \mathrm{Aa}$ & $0.5 \mathrm{Ab}$ & $29.0 \mathrm{Aa}$ & $0.5 \mathrm{Bb}$ \\
\hline 5.5 sieve-classifier & $18.5 \mathrm{Aa}$ & $1.0 \mathrm{Ab}$ & $6.5 \mathrm{Aa}$ & $2.0 \mathrm{Ab}$ & $19.0 \mathrm{Ba}$ & $3.5 \mathrm{Bb}$ \\
\hline 6.0 sieve-gravity table & $11.5 \mathrm{Ba}$ & $0 \mathrm{Ab}$ & $1.0 \mathrm{Ba}$ & $0.5 \mathrm{Ab}$ & $23.0 \mathrm{Ba}$ & $0 \mathrm{Bb}$ \\
\hline 5.5 sieve-gravity table & $9.0 \mathrm{Ba}$ & $1 \mathrm{Ab}$ & $2.0 \mathrm{Ba}$ & $0.5 \mathrm{Ab}$ & $16.0 \mathrm{Ba}$ & $0 \mathrm{Bb}$ \\
\hline CV (\%) & \multicolumn{2}{|c|}{30.6} & 40 & & \multicolumn{2}{|c|}{32.4} \\
\hline
\end{tabular}

*WO/F - Soybean seeds without treatment with fungicide; ${ }^{*} \mathrm{~W} / \mathrm{F}$ - Soybean seeds treated with fungicide; Means followed by the same letter, lowercase in the row and uppercase in the column for each fungus, do not differ by the Scott-Knott criterion $(P>0.05)$ 
The infestation of Fusarium sp. was lower after the gravity table, regardless of the size of the sieve, 6.0 or 5.5. Bicca et al. (1998), working with rice seeds, observed a significant improvement in the sanitary quality of the seeds when they were processed on the gravity table, due to the decrease in the percentage of Fusarium sp. Based on these results, it can be inferred that there is a relationship between the specific mass and the incidence of pathogens in the seeds, because the infested seeds, besides low density, showed reduction in germination and vigor.

Penicillium spp., when associated with soybean seeds, is considered as storage fungus, which can cause deterioration of the seeds in the soil or the death of the seedlings (Barros \& Juliatti, 2012).

The mean temperature during the storage was $21.0^{\circ} \mathrm{C}$, with mean maximum of $27.2^{\circ} \mathrm{C}$, mean minimum of $15.0^{\circ} \mathrm{C}$ and mean relative humidity of $72 \%$ (Figure 1 ).

The mean water content after six months of storage did not differ between the samples collected at the different points, but varied from 10.7 to $11.6 \%$ between treatments, under these storage conditions.

There was a significant reduction in the mechanical damages, especially in the stages after the 5.5 sieve-classifier and the 6.0 and 5.5 sieve-gravity table (Table 4). According to Maryam \& Oskouie (2011), 10\% or more of damages in the hypochlorite test indicate that the physiological quality of the seed lot is compromised. This high percentage of damages can be attributed to problems during the mechanical harvest, in the drying or during the processing. Martin et al. (2007) report that $29 \%$ of mechanical damages in corn seeds lead to a deterioration 2 to 3 times faster in comparison to undamaged seeds. Sweet corn seeds with mechanical injury and stored for five months in a controlled environment did not show significant reductions in germination or health, and the impacts on vigor were low both at the beginning and at the end of the storage (Gomes Júnior \& Cicero, 2012).

The mechanical damages decreased the quality of soybean seeds, because there was a reduction in the germination and vigor of the seeds sampled during the processing and after 180 days of storage in an environment with no control of temperature and relative humidity. There was no difference

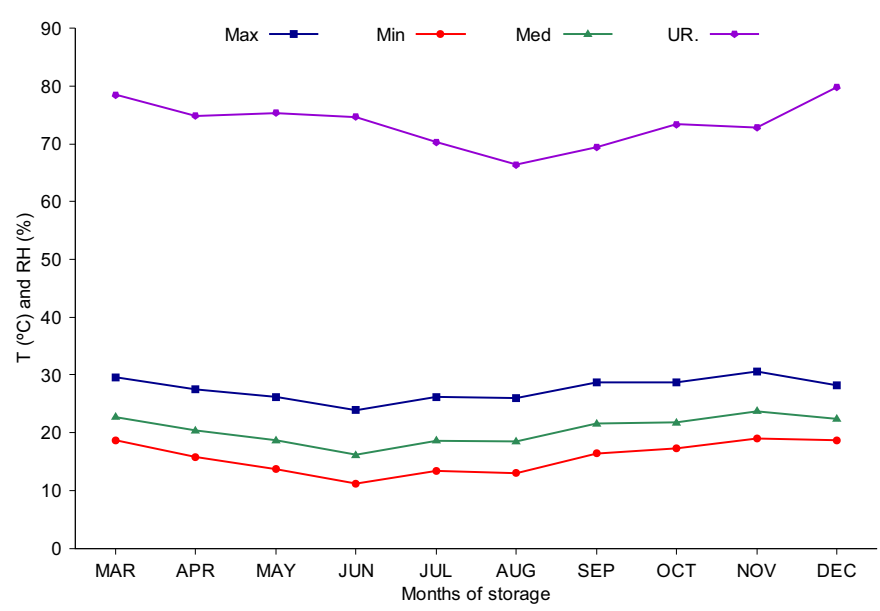

Figure 1. Mean values of maximum, minimum and mean temperature $\left(\mathrm{T},{ }^{\circ} \mathrm{C}\right)$ and mean relative air humidity $(\mathrm{RH}$, $\%)$ during the storage period
Table 4. Mean values of mechanical damages, viability potential by tetrazolium (TZ 1-5), germination (G\%), electrical conductivity $(\mathrm{EC})$ and accelerated aging $(\mathrm{AA} \%)$ of soybean seeds during the processing and the respective coefficients of variation (CV\%) after 180 days of storage in environment with no control of temperature and relative humidity

\begin{tabular}{lccccc}
\hline $\begin{array}{c}\text { Points } \\
\text { of collection }\end{array}$ & $\begin{array}{c}\text { Hypochlorite } \\
(\%)\end{array}$ & $\begin{array}{c}\text { TZ } \\
(\mathbf{1 - 5} \%)\end{array}$ & $\begin{array}{c}\mathbf{G} \\
(\mathbf{\%})\end{array}$ & $\begin{array}{c}\text { EC } \\
\boldsymbol{\mu} \mathbf{~ c m}^{-1} \mathbf{~}^{-1}\end{array}$ & $\begin{array}{c}\text { AA } \\
(\%)\end{array}$ \\
Hopper & $29.5 \mathrm{~A}$ & $57.0 \mathrm{~B}$ & $17.50 \mathrm{D}$ & $161.5 \mathrm{~B}$ & $15.7 \mathrm{~B}$ \\
Pre-cleaning & $22.0 \mathrm{~B}$ & $66.0 \mathrm{~B}$ & $22.50 \mathrm{D}$ & $152.0 \mathrm{~B}$ & $17.5 \mathrm{~B}$ \\
Dryer & $25.5 \mathrm{~A}$ & $61.0 \mathrm{~B}$ & $19.75 \mathrm{D}$ & $162.0 \mathrm{~B}$ & $13.0 \mathrm{~B}$ \\
Cleaning & $29.0 \mathrm{~A}$ & $68.0 \mathrm{~A}$ & $18.75 \mathrm{D}$ & $160.0 \mathrm{~B}$ & $15.0 \mathrm{~B}$ \\
Spiral & $27.0 \mathrm{~A}$ & $71.5 \mathrm{~A}$ & $29.00 \mathrm{C}$ & $155.0 \mathrm{~B}$ & $21.5 \mathrm{~A}$ \\
6.0 sieve-classifier & $26.5 \mathrm{~A}$ & $77.0 \mathrm{~A}$ & $29.75 \mathrm{C}$ & $169.0 \mathrm{~B}$ & $18.5 \mathrm{~A}$ \\
5.5 sieve-classifier & $23.5 \mathrm{~B}$ & $72.0 \mathrm{~A}$ & $30.25 \mathrm{C}$ & $165.0 \mathrm{~B}$ & $18.0 \mathrm{~B}$ \\
6.0 sieve-gravity table & $20.0 \mathrm{~B}$ & $75.5 \mathrm{~A}$ & $41.75 \mathrm{~A}$ & $134.5 \mathrm{~A}$ & $23.0 \mathrm{~A}$ \\
5.5 sieve-gravity table & $23.5 \mathrm{~B}$ & $72.5 \mathrm{~A}$ & $36.00 \mathrm{~B}$ & $146.0 \mathrm{~A}$ & $20.0 \mathrm{~A}$ \\
CV (\%) & 13.6 & 8.4 & 10.3 & 10.0 & 15.4 \\
\hline
\end{tabular}

Means followed by the same uppercase letter in the column do not differ by the Scott-Knott criterion $(p>0.05)$

between the treatments (points of collection) with seeds treated and not treated with fungicides. On average, there were 20.5 and $15.5 \%$ of normal seedlings in the accelerated aging test, for treated and untreated seeds, respectively, evidencing a positive effect of the chemical treatment after 180 days of storage.

There was an increment in the percentage of normal seedlings, according to the germination test, during the processing stages; the seeds collected in the pre-cleaning and dryer showed lower percentage of germination (Table 4). This can be explained by the large amount of seeds with mechanical damages, which can cause reduction in germination (Shelar, 2008). The percentage of normal seedlings was higher for seeds collected after the 6.0 sieve-gravity table.

The viability potential evaluated by the tetrazolium test (TZ 1-5) was lower for seeds collected in the treatments after hopper, pre-cleaning and dryer (Table 4); although the viability potential increased in the stages after pre-cleaning, it did not achieve the minimum standard established for the marketing of soybean seeds, which is $80 \%$, due to the high percentage of damages, which probably occurred during the process of mechanical harvest and/or in the drying of soybean seeds.

According to the results of the electrical conductivity test, there was higher leaching of solutes due to the mechanical injuries occurred during the drying and processing (Table 4); however, there was an improvement of seed vigor after the processing on the gravity table. These results were higher than the values proposed by Vieira (1994) to characterize lots of soybean seeds as of high vigor with electrical conductivity of up to $70-80 \mu \mathrm{Sm}^{-1} \mathrm{~g}^{-1}$. However, it should be pointed out that the results may vary from cultivar to cultivar.

The damages caused along the processing stages of the stored soybean seeds were harmful to their quality, compromising the integrity of the cell membranes, evidenced by the greater leaching of solutes (Paiva et al., 2000). According to Maryam \& Oskouie (2013), unstructured membranes and damaged cells are generally associated with the process of seed deterioration, causing low percentage of germination and vigor.

The accelerated aging test showed that, after the seeds are processed on the gravity table, there is an increase in the 
percentage of normal seedlings, which is positive for their physiological quality. Thus, similar results were observed for corn seeds (Ferreira \& Sá, 2010), broccoli (Gadotti et al., 2006) and fodder radish (Nery et al., 2009).

It is observed that, after 180 days, the treatment with fungicide was highly efficient in the control of Aspergilus spp., Cladosporium sp. and Penicillium sp. (Table 5). On the other hand, the treatment without fungicide showed higher incidence of these fungi, especially in the stages of pre-cleaning, with reduction in the incidence along the processing.

Similar results were obtained by Maciel et al. (2005), who worked with soybean seeds, cv. IAC-18, and observed that, from the fourth month of storage on, the seeds showed higher indices of Aspergillus sp. and Penicillium sp. According to Lima et al. (2014), these fungi are considered as storage fungi and can cause deterioration and reduction in the quality of the soybean seeds during the period of storage.

Cardoso et al. (2004) also reported that the incidence of Aspergillus spp. and Penicillium spp. increased during the storage, especially when the seeds were not treated with fungicide.

Table 5. Percentage of occurrence of Aspergilus spp., Cladosporium sp. and Penicillium sp., associated with soybean seeds and the respective coefficients of variation $(\mathrm{CV} \%)$ after 180 days of storage in environment with no control of temperature and relative humidity

\begin{tabular}{|c|c|c|c|c|c|}
\hline \multirow{2}{*}{$\begin{array}{c}\text { Points } \\
\text { of collection }\end{array}$} & \multicolumn{3}{|c|}{ Aspergilus sp. Clasdosporium sp. } & \multicolumn{2}{|c|}{ Penicillium sp. } \\
\hline & WO/F $W / F$ & W0/F & $W / F$ & WO/F & $W / F$ \\
\hline Hopper & $16.0 \mathrm{Aa} \quad 0 \mathrm{Ab}$ & $12.5 \mathrm{Aa}$ & $0 A b$ & $24.0 \mathrm{Aa}$ & $\mathrm{OBb}$ \\
\hline Pre-cleaning & $7.0 \mathrm{Ba} \quad 0.5 \mathrm{Ab}$ & $10.0 \mathrm{Aa}$ & $0 \mathrm{Ab}$ & $15.5 \mathrm{Ba}$ & $\mathrm{OBb}$ \\
\hline Dryer & $11.0 \mathrm{Aa} \quad 0 \mathrm{Ab}$ & $5.5 \mathrm{Ba}$ & $0.5 \mathrm{Ab}$ & $17.0 \mathrm{Ba}$ & $\mathrm{OBb}$ \\
\hline Cleaning & $8.0 \mathrm{Ba} \quad 0.5 \mathrm{Ab}$ & $7.5 \mathrm{Aa}$ & $0 A b$ & $11.0 \mathrm{Ca}$ & $0.5 \mathrm{Bb}$ \\
\hline Spiral & $4.0 \mathrm{Ca} \quad 0 \mathrm{Ab}$ & $1.5 \mathrm{Ca}$ & $0 A b$ & $11.5 \mathrm{Ca}$ & $\mathrm{OBb}$ \\
\hline 6.0 sieve-classifier & $6.0 \mathrm{Ba} \quad 0 \mathrm{Ab}$ & $3.0 \mathrm{Ca}$ & $0 \mathrm{Ab}$ & $13.5 \mathrm{Ba}$ & $3.5 \mathrm{Ab}$ \\
\hline 5.5 sieve-classifier & $4.0 \mathrm{Ca} \quad 1.5 \mathrm{Ab}$ & $6.0 \mathrm{Ba}$ & $0 \mathrm{Ab}$ & $5.5 \mathrm{Da}$ & $0 \mathrm{Ab}$ \\
\hline 6.0 sieve-gravity table & $2.0 \mathrm{Ca} \quad 0 \mathrm{Ab}$ & $4.0 \mathrm{Ba}$ & $0 \mathrm{Ab}$ & $6.0 \mathrm{Da}$ & $0 \mathrm{Ab}$ \\
\hline 5.5 sieve-gravity table & $2.5 \mathrm{Ca}$ & $5.0 \mathrm{Ba}$ & $0 \mathrm{Ab}$ & $5.5 \mathrm{Da}$ & $0.5 \mathrm{Bb}$ \\
\hline CV (\%) & 33.50 & & 47 & 30. & \\
\hline
\end{tabular}

\section{Conclusions}

1. The processing improves the quality attributes of soybean seeds along the different stages, and the gravity table plays an important role in the improvement of the physiological and sanitary quality of the lot, favoring the vigor of the seeds.

2. The treatment of the seeds with the fungicides Carbendazim + Thiram is efficient in the control of the fungi Cladosporium sp., Fusarium sp., Penicillium sp. and Aspergilus sp. before and after storage.

3. The storage of soybean seeds with high level of mechanical damages markedly increases their deterioration.

\section{Literature Cited}

Barros, F. C.; Juliatti, F. C. Levantamento de fungos em amostras recebidas no laboratório de micologia e proteção de plantas da Universidade Federal de Uberlândia, no período 2001-2008. Bioscience Journal, v.28, p.77-86, 2012.
Bicca, F. M.; Baudet, L.; Jaimezimmer, G. Separação de sementes manchadas de lotes de sementes de arroz, utilizando a mesa de gravidade e sua influência na qualidade sanitária. Revista Brasileira de Sementes, v.20, p.106-111, 1998. http://dx.doi. org/10.17801/0101-3122/rbs.v20n1p106-111

Brasil. Ministério da Agricultura, Pecuária e Abastecimento. Regras para análise de sementes. Brasília: SNDA/DNDV/CLAV, 2009. 399p.

Cardoso, P. C.; Baudet, L.; Peske; S. T.; Lucca Filho, O. A. Armazenamento em sistema a frio de sementes de soja tratadas com fungicida. Revista Brasileira de Sementes, v.26, p.15-23, 2004. http://dx.doi.org/10.1590/S0101-31222004000100003

Ferreira, R. L.; Sá, M. E. Contribuição de etapas do beneficiamento na qualidade fisiológica de sementes de dois híbridos de milho. Revista Brasileira de Sementes, v.32, p.99-110, 2010. http:// dx.doi.org/10.1590/S0101-31222010000400011

Fessel, S. A.; Barreto, A. Avaliação da qualidade fisiológica e sanitária de sementes de amendoim durante o beneficiamento. Revista Brasileira de Sementes, v.22, p.126-130, 2000. http://dx.doi. org/10.17801/0101-3122/rbs.v22n2p126-130

França Neto, J. B.; Krzyzanowski, F. C.; Costa, N. P. Metodologia do teste de tetrazólio em sementes de soja. In: Krzyzanowski, F. C.; Vieira, R. D.; França Neto, J. B. (ed.). Vigor de sementes: Conceitos e testes. Londrina: Associação Brasileira de Tecnologia de Sementes, 1999. cap. 8, p.1-28.

Gadotti, G. I.; Correa, C. L.; Lucca Filho, O. A.; Villela, F. A. Qualidade de sementes de couve brócolis beneficiadas em mesa densimétrica. Revista Brasileira de Sementes, v.28, p.123-127, 2006. http:// dx.doi.org/10.1590/S0101-31222006000200016

Giomo, G. S.; Razera, L. F.; Gallo, P. B. Beneficiamento e qualidade de sementes de café arábica. Bragantia, v.63, p.291-297, 2004. http:// dx.doi.org/10.1590/S0006-87052004000200014

Giurizatto, M. I. K.; Robaina, A. D.; Gonçalves, M. C.; Marchetti, M. E. Qualidade fisiológica de sementes de soja submetidas ao hidrocondicionamento. Acta Scientiarum Agronomy, v.30, p.711717, 2008. http://dx.doi.org/10.4025/actasciagron.v30i5.5972

Gomes Júnior, F. G.; Cícero, S. M. X-Ray analysis to assess mechanical damage in sweet corn seeds. Revista Brasileira de Sementes, v.34, p.78-85, 2012. http://dx.doi.org/10.1590/S010131222012000100010

Krzyzanowski, F. C.; França Neto, J. B. F.; Costa, N. P. Teste do hipoclorito de sódio para semente de soja. Londrina: Embrapa CNPF, 2004. 4p. Circular Técnica, 37

Lima, J. M. E.; Smiderle, O. J.; Alves, J. M. A.; Chagas, E. A.; Souza, A. G. Tipos de adubação e épocas de avaliação na sanidade e viabilidade de sementes de soja-hortaliças. Revista Agro@ mbiente, v.8, p.244-252, 2014.

Lopes, M. M.; Prado, M. O. D.; Sader, R.; Barbosa, R. M. Efeitos dos danos mecânicos e fisiológicos na colheita e beneficiamento de sementes de soja. Bioscience Journal, v.27, p.230-238, 2011.

Maciel, C. D. G.; Poletine, J. P.; Pereira, J. C.; Mondini, M. L. Avaliação da qualidade de sementes de soja (Glycine max (L.) cultivar IAC18. Revista Científica Eletrônica de Agronomia, v.4, p.1-14, 2005.

Martin, T. N.; Tomazella, A. L.; Cícero, S. M.; Dourado Neto, D.; Favarin, J. L.; Vieira, P. A. J. Questões relevantes na produção de sementes de milho segunda parte. Revista da FZVA, v.14, p.80-101, 2007. 
Maryam, D.; Oskouie, B. Study the effect of mechanical damage at processing on soybean seed germination and vigor. Journal of Agricultural and Biological Science, v.6, p.60-64, 2011.

Maryam, D.; Oskouie, B. Study the effect of different seed moisture contents at harvest (before processing) on soybean seed cultivars germination and vigor. Technical Journal of Engineering and Applied Sciences, v.3, p.34-38, 2013.

Nery, M. C.; Carvalho, M. L. M.; Oliveira, J. A.; Kataoka, V. Y. Beneficiamento de sementes de nabo forrageiro. Revista Brasileira de Sementes, v.31, p.36-42, 2009.

Oliveira, A.; Sader, R.; Krzyzanowski, F. C. Danos mecânicos ocorridos no beneficiamento de sementes de soja e suas relações com a qualidade fisiológica. Revista Brasileira de Sementes, v.21, p.5966, 1999. http://dx.doi.org/10.17801/0101-3122/rbs.v21n1p59-66

Paiva, L. E.; Medeiros Filho, S.; Fraga, A. C. Beneficiamento de sementes de milho colhidas mecanicamente em espigas: Efeitos sobre danos mecânicos e qualidade fisiológica. Ciência e Agrotecnologia, v.24, p.846-856, 2000.
Shelar, V. R. Role of mechanical damage in deterioration of soybean seed quality during storage. Agricutural Reviews, v.29, p.177-184, 2008.

Silva, H. P.; Brandão Júnior, D. S.; Neves, J. M. G.; Sampaio, R. A.; Duarte, R. F.; Oliveira, A. S. Qualidade de sementes de Helianthus annuus L. em função da adubação fosfatada e da localização na inflorescência. Ciência Rural, v.41, p.1160-1165, 2011a. http:// dx.doi.org/10.1590/S0103-84782011000700009

Silva, R. P.; Teixeira, I. R.; Devilla, I. A.; Rezende, R. C.; Silva, G. C. Qualidade fisiológica de sementes de soja (Glycine max L.) durante o beneficiamento. Semina: Ciências Agrárias, v.32, p.1219-1230, 2011b. http://dx.doi.org/10.5433/1679-0359.2011v32n4p1219

Vieira, R. D. Teste de condutividade elétrica. ln: Vieira, R. D.; Carvalho, N. M. (ed.). Testes de vigor em sementes. Jaboticabal: FUNEP, 1994. p.103-132.

Vieira, R. D.; Krzyzanowski, F. C. Teste de condutividade elétrica. In: Krzyzanowski, F. C.; Vieira, R. D.; França Neto, J. B. (ed.). Vigor de sementes: Conceitos e testes. Londrina: ABRATES, 1999. cap.4, p.1-26. 